UDC 343.195

DOI https:// doi.org/10.32850/2414-4207.2019-9.29

\title{
NORMATIVE-LEGAL SUPPORT OF JURY ACTIVITY IN UKRAINE
}

\author{
Chesak Viktoriya Volodymyrivna, \\ Postgraduate Student Department of \\ International Law and Comparative Law \\ (National University of Life and \\ Environmental Sciences of Ukraine, \\ Kyiv, Ukraine)
}

Civil society's involvement in the judicial process is foreseen by the creation of an appropriate new institute, the "jury". Given that this brand new institute is fundamentally different from the previous "people's assessors", the issue of jury formation and functioning is very relevant and important for both society and the judiciary. Citizens' involvement, their awareness, principle and willpower in decision-making should positively affect confidence in the judiciary.

Analyzing the latest scientific research, we can conclude that the public's attention has increased not only to the problems of the judiciary in general, but also to the institute of jury, which, in turn, is designed to ensure the exercise of the right of the population to participate in the administration of justice.

Introducing a jury institute has both advantages and disadvantages. First of all, it is positive to create the possibility of complete or partial elimination of manifestations of corruption in the judicial system. Legislative consolidation of the basic principles of the jury's operation makes it possible to ensure a "peculiar conditional" division of the judicial power into two relatively independent institutions: a jury and a professional judge, who control each other, which creates additional levers of restraint and counterbalances and possibilities errors of law.

It should be noted that not less important and positive consequence of introduction of this institute is awakening of the legal consciousness of citizens, raising the level of their legal culture, studying national legislation and its practical application, since their direct involvement in the administration of justice will promote awareness of the need for such knowledge.

The article were analyzed the existing norms of Ukrainian legislation in the sphere creation and activities of the institute jury trial and were suggested some changes to them in order to implement right on a fair decision and the right to citizen participation in exercise of justice guaranteed by international norms and by the Constitution of Ukraine. The defects are identified and it is proposed to adopt a normative act, which will detail the procedure for trial by a jury.

Key words: jury trial, jury, professional judges, court proceedings, court proceedings, normative acts.

\section{НОРМАТИВНО-ПРАВОВЕ ЗАБЕЗПЕЧЕННЯ ДІЯЛЬНОСТІ ПРИСЯЖНИХ В УКРАЇНІ}

\author{
Чесак Вікторія Володимирівна, \\ аспірант кафедри міжнародного права \\ та порівняльного правознавства \\ (Національний університет біоресурсів \\ і природокористування України, \\ м. Київ, Україна)
}

Участь громадянського суспільства у процесах судочинства передбачена створенням відповідного нового інституту - «суду присяжних». Враховуючи, що цей зовсім 
новий інститут принципово відрізняється від попередніх «народних засідателів», питання формування і функціонування інституту присяжних дуже актуальне та важливе як для суспільства, так і для судової гілки влади. Участь громадян, їхня обізнаність, принциповість і волевиявлення у прийнятті судових рішень повинні позитивно вплинути на довіру до судової системи.

Проаналізувавши останні наукові дослідження, можна зробити висновок, що зросла увага громадськості не лише до проблем діяльності судової влади взагалі, але й до інституту суду присяжних, який, у свою чергу, покликаний забезпечити реалізацію права населення на участь у здійсненні правосуддя.

Запровадження в дію інституту суду присяжних має низку як переваг, так і недоліків. Насамперед, позитивним є створення можливості повної або часткової ліквідації проявів корупції у системі судочинства. Законодавче закріплення основних засад функціонування суду присяжних дає можливість забезпечити «своєрідний умовний» поділ судової влади на дві відносно самостійні інституції: суд присяжних і професійного суддю, які контролюють один одного, що створює додаткові важелі стримувань і противаги проти свавілля й можливих проявів корупції та зменшує можливості судових помилок.

Слід зазначити, що не менш важливим і позитивним наслідком запровадження цього інституту є пробудження правової свідомості громадян, підвищення рівня їхньої правової культури, вивчення національного законодавства та практичне його застосування, оскільки безпосереднє їх залучення до здійснення правосуддя сприятиме усвідомленню необхідності таких знань.

У статті проведено аналіз чинних норм законодавства України у сфері створення та діяльності інституту суду присяжних і запропоновано певні зміни до них із метою реалізації гарантованого міжнародними нормами права та Конституцією України права на справедливе рішення у справі і права на участь громадян у здійсненні правосуддя. Також запропоновано прийняти нормативний акт, який деталізуватиме порядок судового розгляду судом присяжних.

Ключові слова: суд присяжних, присяжні, професійні судді, судочинство, судовий розгляд, нормативні акти.

Formulation of the problem. One of the main elements of the judicial system of many states is the involvement of citizens in the administration of justice: both through the jury and through the court of the chefs. The activities of the jury are carried out in accordance with the regulations in force. The lack of clear and effective regulation leads to gaps in the practice of judicial and law enforcement agencies.

The involvement of civil society in the judicial process is foreseen by the creation of a new institute - the "jury trial". Given that this entirely new institution is fundamentally different from the previous "people's assessors", the question of the formation and functioning of the jury is very relevant and important both for the society and for the judicial branch of government. Participation of citizens, their awareness, principledness and expression of will in making court decisions should positively affect trust in the judicial system [7].

Of course, the institute of the jury in Ukraine eliminated gaps in the system of judicial power and justice, provided citizens with the opportunity to administer justice through jurors.

In this regard, the normative and legal support of the activity of the jury in Ukraine is particularly relevant.

State of the study. Separate aspects of the legal regulation of consideration of the case in the jury were reflected in works of U. Alenin, U. Groshevoi, V. Gorovovenko, V. Malyarenko, P. Pylypchuk, I. Rusanov, M. Grai, V. Teremetsky, V. Tertyshnik, V. Shishkin and other scholars. 
The purpose of the article is to analyze the legal and regulatory framework for the activities of the jury in the legal process of Ukraine in order to optimize it.

Presenting main material. In 2006, the practice of the Bangalore Principles of Judicial Conduct (commonly accepted standards regulating the activity of courts at the international level) was extended on the territory of Ukraine. According to them, some emphasis was placed on the settlement of relations between judges and jurors. The judge maintains the procedure and observes etiquette in the course of all court proceedings and behaves patiently, duly and courteously on the parties to the court, jurors, witnesses, lawyers and other persons with whom the judge communicates in its official capacity. A similar behavior was demanded by this international treaty from persons participating in a court session [2, p. 26].

In clause C of Art. 1 of the Additional Protocol to the Criminal Law Convention on Corruption (ETS 191), ratified by Ukraine on October 18, 2006, provides an international interpretation of the term "juror's assessor". The possibility of a specific definition of this definition was established by the parties to this Protocol. However, this concept must necessarily include a person acting as a member of the collegial body, which should determine the guilt of the accused during the trial [3].

Also, the Bordeaux Declaration, adopted on November 18, 2009, reduced the task of judges and, where applicable, jury trials, to due consideration of cases without any undue influence from the prosecution or defense, or any other party [1].

It should be noted that the activities of the jury are provided by the norms of the national legislation. In accordance with the Constitution of Ukraine, the people directly participate in the implementation of justice through the jury [5].

However, the listed norms for a considerable period of time were only declarative, without being enshrined in legislative acts and practice. The situation has changed with the adoption of the Criminal Procedural Code of Ukraine of April 13, 2012, which came into force on November 20, 2012. At the same time, a number of significant changes were made to the Law of Ukraine "On the Judiciary and Status of Judges", which regulated the status, powers and responsibility of jurors.

That is why these constitutional provisions are not only reproduced in the Law of Ukraine "On the Judiciary of Ukraine" of 02.06.2016, but also specified in its provisions.

Consequently, in accordance with the norms enshrined in the Basic Law of our state, the authorities should provide citizens with their constitutional right to participate in the administration of justice through jurors. This is to mean participation in the administration of justice provided and guaranteed by the state, enshrined in the Constitution of Ukraine and indispensable for executive, legislative and judicial authorities, the right of a citizen in the forms established by law to be an active participant in the administration of justice. Although at this stage there are problems with the introduction of the jury in our state. The most important problem is that the Constitution of Ukraine only proclaims the right of the accused to the jury, while not giving any provisions on the construction and operation of the court, the procedural rights and duties of the jury are not defined. It is necessary to clearly define the model of the jury trial institution.

On May 10, 2006, the Decree of the President of Ukraine approved the Concept for the improvement of the judiciary for the establishment of a fair court in Ukraine in accordance with European standards. In Part 2 of Section 4 it was noted that the activities of the jury should be regulated by law, providing for its use only in certain categories of criminal cases. The accused should have the right to choose: his case will be considered by a jury or a panel of professional judges. Functions of jurors should be separated from the functions of a professional judge. Jurors decide in a decision only a matter of legal fact, and professional judge on the basis of jury and the rules of criminal law decree sentence [8]. 
The new institute of jurors began to develop after the decision of the National Security and Defense Council of Ukraine dated February 15, 2008 "On the process of reforming the criminal justice system and law enforcement agencies". According to the provisions of the document, one of the areas of reforming the criminal justice of Ukraine was the consideration of a collective court, with the participation of jurors, criminal proceedings in which the accused are minors [10].

Currently, the jury activity in Ukraine is regulated by the Criminal Procedure Code of Ukraine, the Civil Procedural Code of Ukraine and the Law "On the Judiciary and Status of Judges in Ukraine", according to which the jurors, together with professional judges, are united into a single panel and consider the case in court according to with the law.

The Code of Criminal Procedure of Ukraine contains Chapter 2, which contains only 8 articles devoted to the regulation of proceedings in the jury. Their summary can not answer a lot of discussion issues in the work of the jury.

The Law of Ukraine "On the Judiciary and the Status of Judges" more and more regulated the legal status of the jury, the specificity of the cases to which involved, the requirements for candidates, the grounds and procedure for exemption from duties, guarantees of rights; in resolving all matters relating to the consideration of a case and the issuing of court decisions, they have the same rights as professional judges [9].

In accordance with the law, for approval of the list of jurors, the territorial administration of the State Judicial Administration of Ukraine shall apply to the appropriate local councils that form and approve, in the amount indicated in the submission, a list of citizens permanently residing in the territories covered by the jurisdiction of the relevant district court, meet the established requirements and have agreed to be jurors [6].

It should be noted that this law does not envisage the possibility of a citizen being a juror, that is, the procedure for selecting candidates, criteria for their assessment and election conditions.

In addition, the Law of Ukraine "On the Judiciary and Status of Judges" contains significant gaps in the work of the jury. In particular, according to Clause 6 of Art. 67 of this law, failure to appear without a valid reason in a jury trial is considered to be disrespectful to the court [9].

Responsibility for contempt of court is stipulated in Art. 185-3 of the Code of Ukraine on Administrative Offenses. Obligatory qualifying feature of this administrative offense when evasion from appearance in court is "malice". Anger is determined repeatedly without valid reasons of evasion from appearance in court [4, p. 428]. This means that according to the current wording of the provisions of Art. 185-3 KUpAP is not an offense and does not entail administrative liability for a one-time deliberate failure to appear in a court of a person (including a juror) whose personal participation in court proceedings is considered mandatory. However, because of the absence in the court session of the participants in the trial, the consideration of each second third case is actually postponed.

In the economic, administrative proceedings and in cases of administrative violations, the participation of the people in the implementation of judicial proceedings is not provided for by the current legislation.

As we see, normative certainty and regulation of this institute can not be called complete. The set of normative legal acts, the significant part of which is taken by international documents and documents of recommendation and software value, has a scattered character. In support of this, it is possible to specify the provisions of the letter of judges of the Supreme Court of Ukraine regarding the Law of Ukraine "On the Judiciary and Status of Judges" [9]. In it, judges complained that the right of the people to directly administer justice by jury trial again at an indefinite time remains at the level of the declaration, which makes it impossible for the people to exercise legitimate forms of effective control over power. During the last two years legislative innovations have been made that will enable the institute of jurors to enter the territory of our country, but they are also not without flaws. 
Therefore, it is necessary to legislatively regulate the procedure for the exercise of jurors' powers by a separate normative act in which to highlight their powers, the procedure for conducting court proceedings, to determine the list of criminal proceedings in which they must take part and responsibility for failure to fulfill their duties.

Conclusions. Thus, the idea of participation of the people in the administration of justice has long been perceived by theory and practice. Effective activity of state bodies is impossible without close and systematic cooperation with the people's element, that is, with citizens and the public, as a powerful regulator of social behavior of citizens is the public opinion of both large and small social groups. By the legal nature of the court with the participation of the people is one of the forms of direct democracy, that is, the way of expressing the will of the people in solving socially important issues.

Therefore, the activity of the jury is carried out in accordance with the current regulations. The lack of clear and effective regulation leads to gaps in practice. That is why it is proposed to detail the procedure for exercising the powers of the jury in a separate normative act in which to determine their powers, the procedure for conducting court proceedings, to determine the list of criminal proceedings in which they must participate and responsibility for failure to fulfill their duties.

\section{References:}

1. Bordeaux Declaration No. 994_a50 of 11/18/2009 / Database "Legislation of Ukraine". VR of Ukraine. URL: http://zakon2.rada.gov.ua/laws/show/994_a50 (date of issue: 02.17.2018).

2. Glovyuk I. The jury's verdict: de lege ferenda. Comparative-analytical law : electron. Sciences. kind. Uzhhorod, 2014. № 5. P. 358-361. URL: http://pap.in.ua/5_2014/107.pdf (accessed: 03.10.2017).

3. Additional Protocol to the Criminal Convention on Corruption of May 15, 2003. No. ETS 191. / Legislation of Ukraine. VR of Ukraine. URL: http://zakon2.rada.gov.ua/ laws/show/994_172/conv/pnntl349712332808772 (date accessed: 02.13.2018).

4. Kalyuzhnyi R., Komzyuk A., Pogribniy O., et al. Scientific and Practical Commentary on the Code of Administrative Offenses. Kyiv : All-Ukrainian Association of Publishers "Legal Unity", 2008. P. 428.

5. Constitution of Ukraine: Law of Ukraine of June 28, 1996. No. 254k / 96-VR / Database "Legislation of Ukraine". VR of Ukraine. URL : http://zakon4.rada.gov.ua/laws/ show $/ 254 \%$ D0\%BA/96\%-D0\%B2\%D1\%80 (accessed 16.02.2018).

6. Criminal Procedure Code of Ukraine : Law of Ukraine of April 13, 2012. No. 4651-VI: as of February 15, 2018 / Database "Legislation of Ukraine". VR of Ukraine. URL: http:/ / zakon2.rada.gov.ua/laws/show/4651\%D0\%B017/print1329932924471.

7. Malyarenko A. On the oath of a judge and responsibility for her violation. Bulletin of the Supreme Court of Ukraine. 2012. No. 2 (138). P. 26-31.

8. On the Concept of Improving Judiciary for the Establishment of a Fair Court in Ukraine in accordance with European Standards: Decree of the President of Ukraine No. 361/2006 of 10.05.2006 / Database "Legislation of Ukraine". VR of Ukraine. URL: http:// zakonl.rada.gov.ua/laws/show/361/2006/conv/printl34987963412739 (accessed 12.09.2017).

9. On the Judiciary and Status of Judges: Law of Ukraine of June 02, 2016. No. 1402-VIII / Database "Legislation of Ukraine". VR of Ukraine. URL: http:/ / zakon2.rada.gov.ua/laws/ show/1402-19.

10. On the course of reforming the criminal justice system and law enforcement agencies: Decision of the National Security and Defense Council of Ukraine N 311/2008 of 08.04.2008 / Database "Legislation of Ukraine". Verkhovna Rada of Ukraine. URL: http:// zakon2.rada.gov.ua/laws/show/n0009525-08 (accessed 03/12/2017). 